\title{
STRATIGRAPHY AND GEOCHEMISTRY OF A FOND ST. JEAN CINDER CONE, DOMINICA
}

TARYN ISENBURG, Mount Holyoke College

Research Advisors: Steve Dunn and Holli Frey

\section{INTRODUCTION}

Dominica is an island nation located near the center of the Lesser Antilles Island Arc, and it is primarily composed of subaerial lava flows and pyroclastic deposits, which give rise to a rugged terrain (Smith et al., 2013). Due to the warm and wet climate, weathering rates are high, and a thick layer of soil covers much of the geology, making it difficult to map. As a result, large portions of the island, especially volcanic centers, are grouped together on geologic maps as large cohesive units. One such unit is Foundland Center, surrounding the historically active Foundland stratovolcano, which is mapped as a 25 $\mathrm{km} 2$ block of mafic flow rocks (Smith et al., 2013).

Foundland Center is unusual in that it is the only mafic volcanic center on the island, which is otherwise composed of intermediate rocks ranging from andesites to dacites (Smith et al., 2013). Previous analyses of rocks from Foundland Center indicate that lapilli collected from Fond St. Jean, a town within Foundland, is some of the most mafic and primitive material from the island (Wills, 1976).

This study analyzes the stratigraphy and geochemistry of geologic material composing a cinder cone at Fond St. Jean. The purpose of this study is to characterize the mineralogy, textures, and composition of the most primitive material on Dominica and determine if it is a parental source to more evolved lavas on the island. A study of the evolution of material emplaced within Foundland may provide insight into the evolution of mafic magma. Furthermore, studying variations in the texture of materials deposited by the cinder cone gives insight into how styles of volcanism changed at Fond St. Jean.

\section{METHODOLOGY}

Fond St. Jean is located on the southeastern shore of Dominica, situated within the Foundland Stratovolcano. A dome shaped structure within Fond St. Jean was identified as a weathered and partially eroded cinder cone. The dome is composed of repetitive layers of massive basaltic flow rocks, scoria, ash, and lapilli units. A continuous outcrop of the material composing the cinder cone is exposed by a road cut, along which all samples and additional data were collected (Fig. 1 a-d). Field work consisted of collecting samples, measuring the thickness of units composing the outcrop, and collecting coordinates and elevation measurements using ArcGIS software.

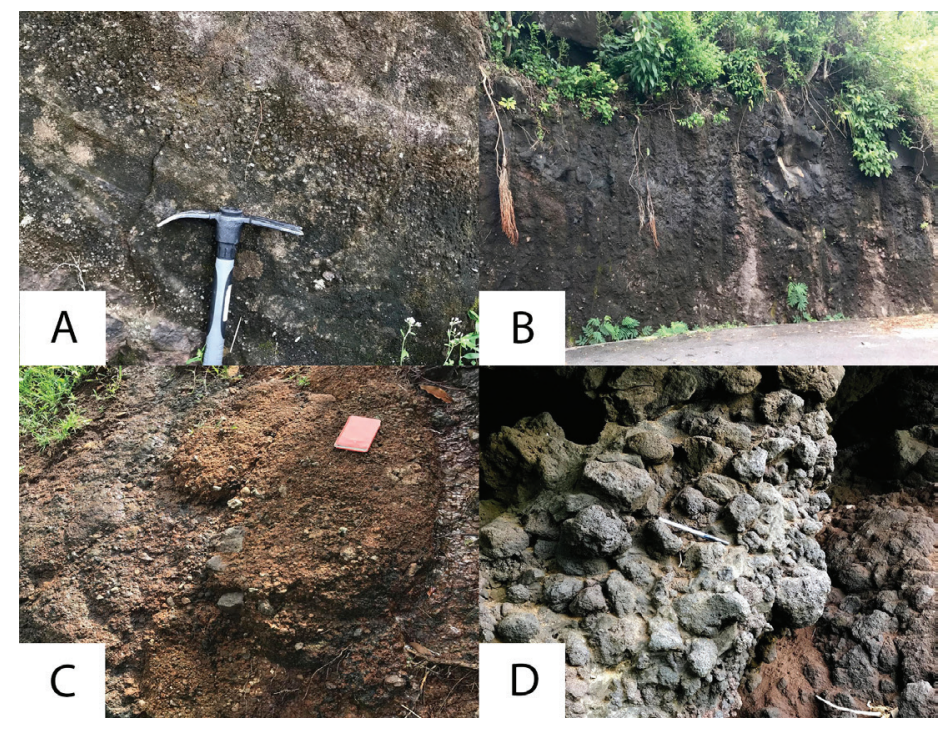

Figure 1. Unit photos taken along the road cut exposing the Fond St. Jean cinder cone. Physical characteristics, textures, and mineralogy separate units such as lapilli in soft flow rocks (a), massive flows (b), brecciated basalt (c), and scoria (d). 
In the lab thin sections of all samples except the lapilli were cut. Lapilli were made into micromounts by selecting the glassiest pieces and placing them into plastic rings, which were then filled with epoxy, cut through the center, and polished. Thin section and micromount mineralogy was analyzed on a petrographic microscope and mineral compositions were analyzed on a scanning electron microscope (SEM) both at Union College and Mount Holyoke College. Plagioclase, olivine, and oxides were the main phases analyzed on the SEM by energy dispersive spectrometry (EDS). Additionally, rock samples were crushed into powders, which were analyzed by inductively coupled plasma optical emission spectrometry (ICP-OES) and inductively coupled plasma mass spectrometry (ICPMS) to determine major element and trace element compositions, respectively. ICP-OES was conducted at Acme Labs in Vancouver, Canada, and ICP-MS was conducted at Union College, following procedures of Hollocher and Joaquin, 1995.

\section{RESULTS}

\section{Stratiography}

The stratigraphic sequence of the cinder cone includes $35 \mathrm{~m}$ of basaltic material including brecciated lava flows, massive flow rocks, scoria, ash, and lapilli (Fig. 2). The sequence begins with a 2-3 m thick basal unit of basaltic breccia overlain by repetitive layers of massive and rubbly flow rocks, which range from 1 to $10 \mathrm{~m}$ in thickness. These flows transition into an additional $2 \mathrm{~m}$ thick scoria deposit capped by a meter of massive basalt, which sits beneath another 3-4 m scoria deposit. Another layer of massive flow then transitions to three units of alternating lapilli and ash lenses. Lapilli units are $0.25 \mathrm{~m}$ in thickness, but pinch and swell regularly, and ash lenses are roughly $0.25 \mathrm{~m}$ thick.

\section{Petrography}

All units contain plagioclase + olivine + clinopyroxene + orthopyroxene + titanomagnetite. Plagioclase is the most dominant phase in each unit, and commonly appears as 1-3 mm scale phenocrysts (Fig. 3a). Plagioclase habit ranges from tabular euhedral to broken and anhedral depending on the unit (Fig. 3a-c). Phenocrysts of olivine and both pyroxenes are equally

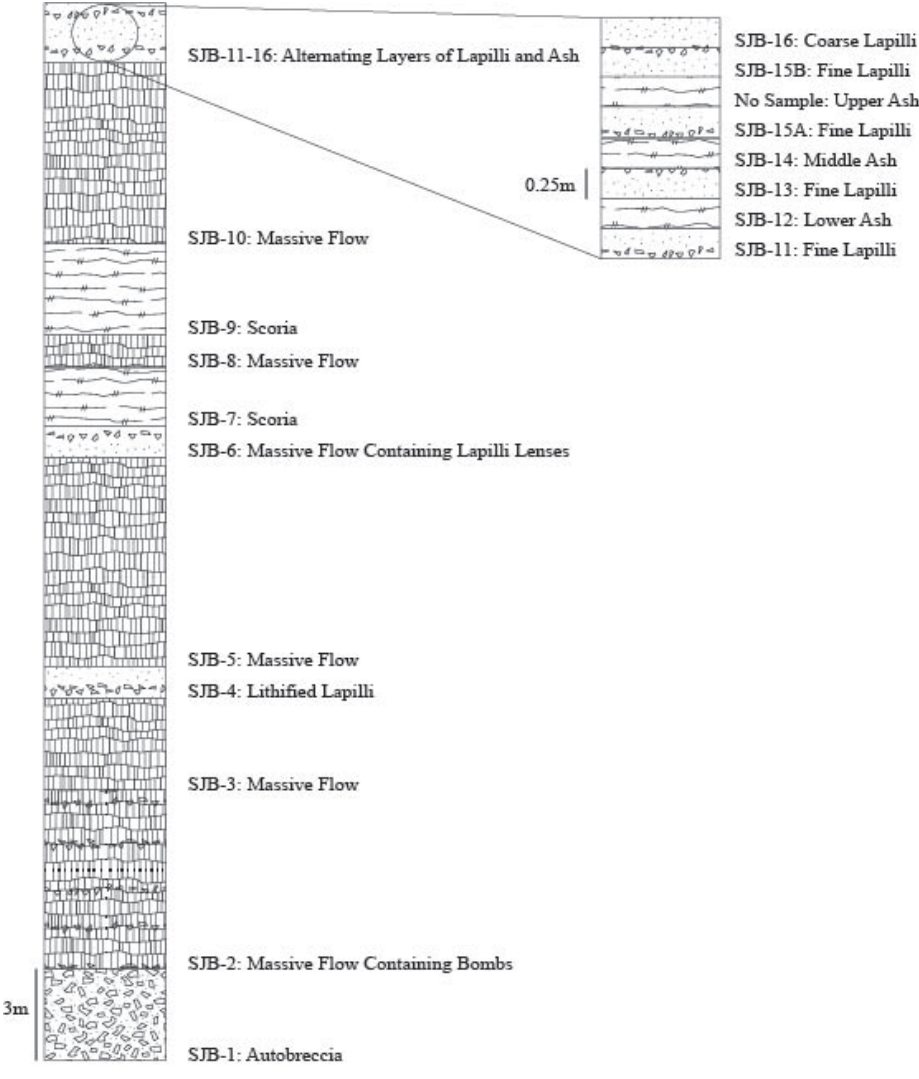

Figure 2. Idealized stratigraphic column of the cinder cone at Fond St. Jean. Overall thickness of the sampled section is $35 \mathrm{~m}$. Unit boundaries were established where changes in the appearance or mineralogy of the outcrop were obvious. The boundary between many units was gradational, so the beginning of a new unit was marked where the rocks completely transitioned into a new appearance, behavior, or mineralogy.

common in thin section, and both appear as single mm scale rounded, subhedral grains (Fig. 3a). Olivine grains are at least partially altered to iddingsite in every unit. Phenocrysts of all minerals are fractured or broken in every unit, but phenocrysts in massive flow units have lighter fractures than phenocrysts in other units. Phenocrysts from ash, lapilli, and scoria units are more likely to contain broken, anhedral grains (Fig. 3c). Titanomagnetites are present throughout the section and occur as poorly mixed sub-mm scale minerals. A matrix of fine grained, intergranular plagioclase, olivine, and pyroxene surrounds phenocrysts in every unit.

Matrix olivine crystals occasionally have reaction rims showing alteration to micron scale pyroxene (Fig. 3d). Other minerals do not consistently show alteration, though plagioclase textures do change based on the unit they are in. Plagioclase in the lapilli and ash units 


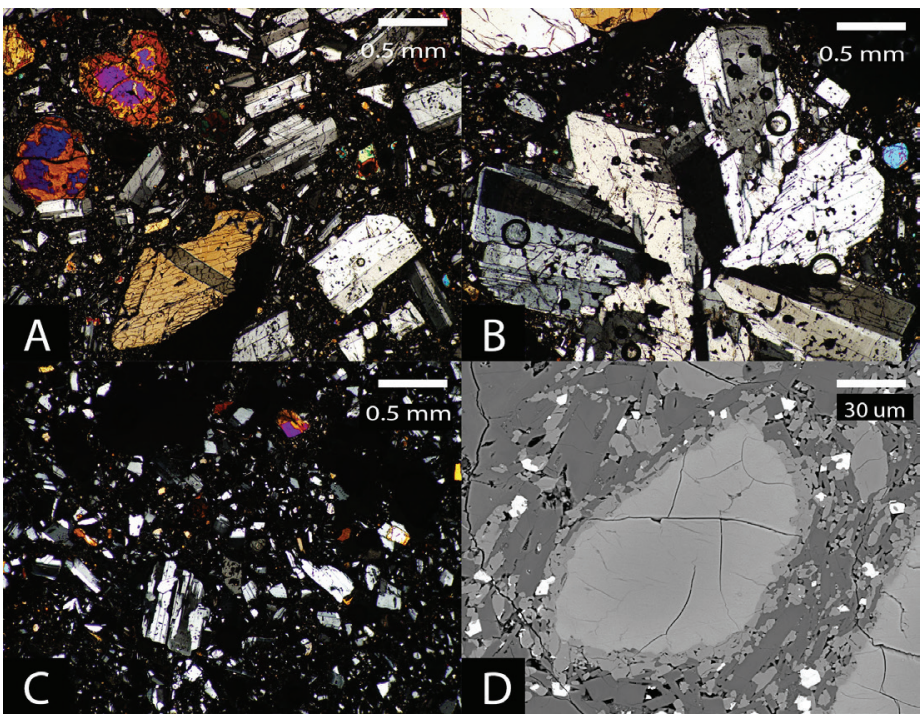

Figure 3. Photomicrographs (3a-c) and a backscattered electron image (3d) of minerals in thin section. SJB-10 (3a, x4 mag.) is a massive flow containing phenocrysts of tabular plagioclase, rounded and subhedral olivine with alteration to iddingsite, and subhedral clinopyroxene, which is partly obscured by a bubble in the thin section. SJB-9 (3b, $x 4$ mag.) is a scoria unit containing large glomerocrysts of plagioclase. SJB-14 (3c, $x 4$ mag.) is an ash unit containing broken phenocrysts of plagioclase, olivine, and both pyroxenes. The brecciated basalt unit SJB-1 (3d) shows matrix olivine with reaction rims altered to pyroxene.

are usually broken and surrounded by intergranular matrix (Fig. 3c). Plagioclase in the massive flows and scoria units are more likely to form glomerocrysts with each other and pyroxene grains (Fig 3b).

\section{Mineral Compositions}

Mineral compositions are similar throughout the stratigraphic column. Massive flows contain similar, weakly zoned plagioclase cores $\left(\mathrm{An}_{84-94}\right)$ with 10-30 $\mu \mathrm{m}$ sodic rims $\left(\mathrm{An}_{58-78}\right.$, most rims are $\left.<\mathrm{An}_{68}\right)$. Plagioclase microlites (long axis $<100 \mu \mathrm{m}$ ) span a wide range of compositions $\left(\mathrm{An}_{50-90}\right)$. Lapilli units contain crystal rims ranging in composition from $\mathrm{An}_{58-86}$ and cores ranging from $\mathrm{An}_{84-92}$, with the exception of a single core with the composition of $\mathrm{An}_{61}$. Scoria units follow a similar trend, with plagioclase cores ranging from $\mathrm{An}_{84-90}$ and rims ranging from $\mathrm{An}_{53-66}$. The autobreccia unit again follows the same trend, with plagioclase cores ranging in composition from $\mathrm{An}_{80-87}$ and rims ranging from $\mathrm{An}_{60-64}$. Olivine in most units ranges in composition from $\mathrm{Fo}_{55-70}$, with the exception of a single lapilli unit where only $\mathrm{Fo}_{55}$ was identified. Spinels are ubiquitous throughout each of the units and are consistently poorly mixed titanomagnetites.

\section{Whole Rock Chemistry}

Compared to other available whole rock analyses (accessed on http://georoc.mpch-mainz.gwdg.de/georoc/ September 28, 2017; Brown et al., 1977; Halama et al., 2006; Howe et al., 2014, 2015; Lindsay et al., 2005; Smith et al., 2013), the samples from Fond St. Jean are basalts and contain the highest amount of iron and magnesium by oxide weight percent and the lowest amount of silica ( $\left.48-50 \mathrm{wt} \% \mathrm{SiO}_{2}\right)$, potassium, and sodium by oxide weight percent of all of the rocks analyzed on Dominica (Fig. 4). Plots of oxide weight percent for each sample vs. the relative height at which they were collected in the stratigraphic column show that major element compositions vary up section, but not systemtically. In general, $\mathrm{SiO}_{2} \mathrm{wt}$ $\%$ gradually decreases up section from $\sim 50 \mathrm{wt} \%$ to $48 \mathrm{wt} \%$. $\mathrm{Al}_{2} \mathrm{O}_{3}$ content gradually increases up section from $\sim 20 \mathrm{wt} \%$ to $23 \mathrm{wt} \%$. $\mathrm{MgO}$ remains relatively consistent at 4-5 wt \% throughout the section.

Rare earth elements from these samples are consistent with typical island arcs, though some samples are slightly less enriched in light rare earth elements and more enriched in heavy rare earth elements (Fig. 4). Discrimination plots show that the majority of samples have major and trace element compositions that are consistent with island arc basalts (Fig. 5). Some samples are slightly depleted in strontium or enriched in zirconium, similar to mid-ocean ridge basalts, but these make up a minority of the samples (Fig. 5). Trace element ratios that may monitor sediment contribution to arc magmas are fairly consistent throughout the column, with $\mathrm{Th} / \mathrm{La}$ ratios ranging from 0.12 to 0.36 (most ratios are $>0.20$ ).

\section{DISCUSSION AND CONCLUSION}

Stratigraphy of the cinder cone, in addition to unit textures that were used to establish boundaries and transitions within the stratigraphic section indicate that both explosive and effusive styles of volcanism were critical during cinder cone deposition. Flow rocks indicate more effusive styles of volcanism whereas brecciated flows, scoria, lapilli, and ash indicate more explosive styles of volcanism. Alternating emplacement of these units alone cannot be used 

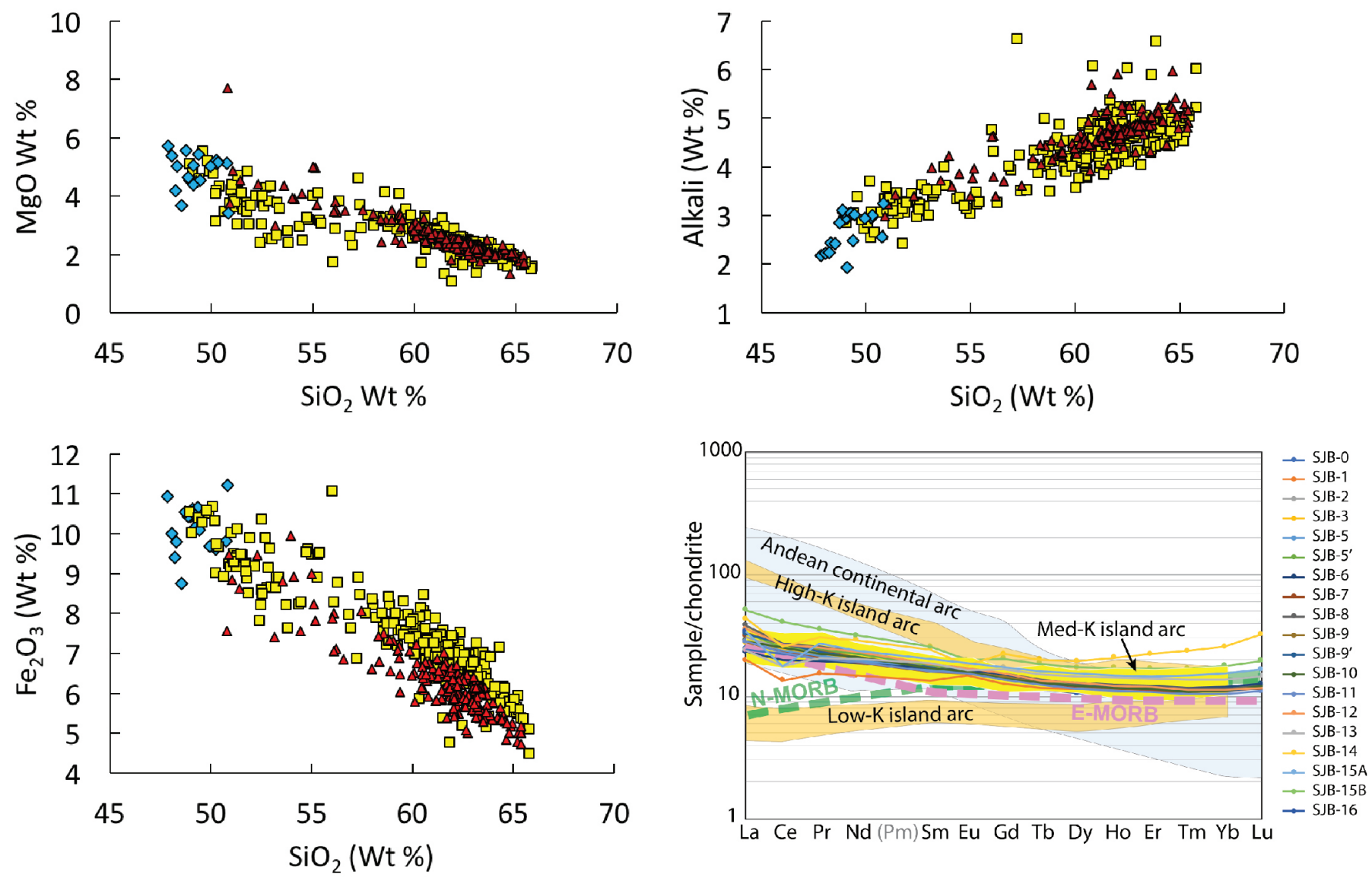

Figure 4. Harker diagrams comparing major element compositions and a rare earth element plot. On the harker diagrams, blue diamonds represent rocks collected in this study. Red triangles represent data collected and shared on the GeoRock database (accessed on http://georoc.mpch-mainz.gwdg.de/georoc/September 28, 2017). Yellow boxes represent data collected by Smith et al. (2013). The rare earth element plot shows that these samples are consistent with medium K island arc rocks. All trace elements are normalized after McDonough and Sun, 1995.

to determine the temporal relationship of eruptive styles, as lava flows can disrupt pyroclastic deposits after emplacement through a number of complex mechanisms (Brown et al. 2015).

Consistency in mineralogy and mineral compositions throughout the stratigraphic section indicates that the material being emplaced did not undergo dramatic evolution as emplacement proceeded in this particular location. Major element compositions are also fairly consistent throughout the column. While some general trends in major element compositions exist for certain oxides, the column does not show consistent and continual increase or decrease in major element oxide compositions. This indicates that magma emplacement was complex and did not simply progress from the most primitive and mafic material to continually more mature material.
The material collected for this study is some of Dominica's most mafic and primitive material on record (Fig. 4). Major and trace element plots provide evidence that these rocks are well behaved island arc basalts (Fig. 5). Trace element ratios, such as Th/La, can be used to track sediment contribution at subduction zones (Plank, 2005). These samples yield Th/La ratios close to $0.2-0.3$, which is consistent with $\mathrm{Th} / \mathrm{La}$ ratios of subducting sediments in the Lesser Antilles (Plank, 2005). These values indicate that the samples collected in this study have been contaminated by sediment contribution instead of being derived directly from uncontaminated mantle, which has $\mathrm{Th} / \mathrm{La}$ ratios closer to 0.1 (Plank, 2005).

A comprehensive study of cumulate blocks from samples throughout the Lesser Antilles provides insight on fractional crystallization processes on each island (Arculus et al. 1980). On Dominica, intermediate 

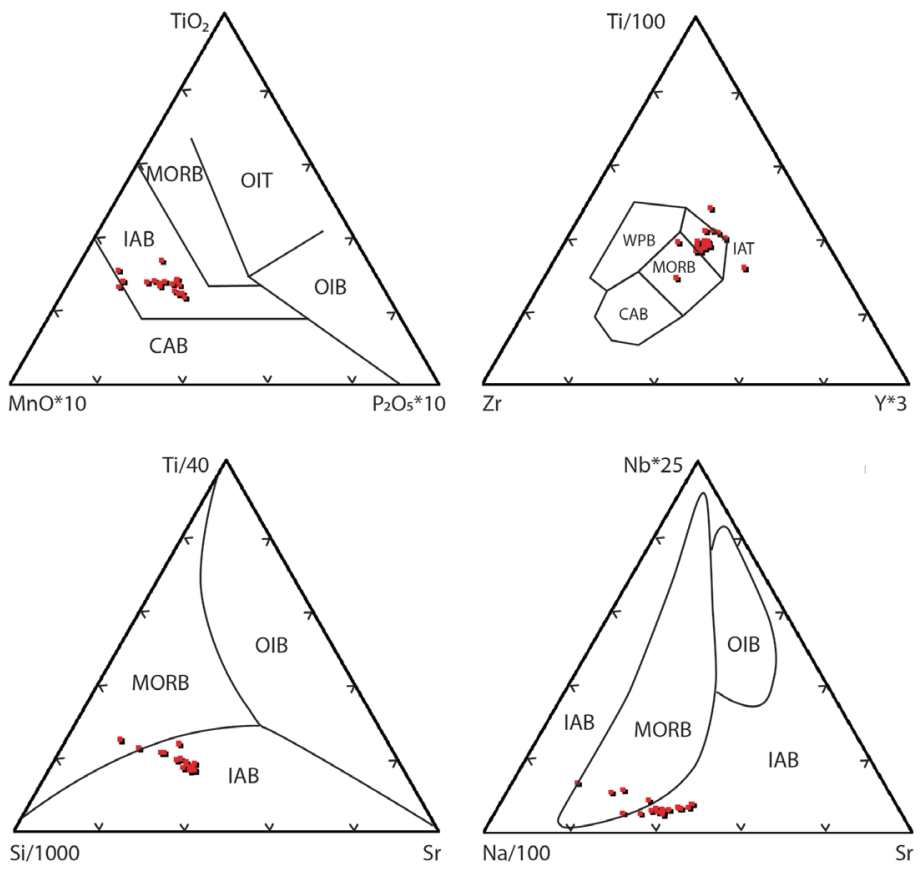

Figure 5. Discrimination diagrams after Vermeesh, 2006. Major and trace elements show that the samples collected at Fond St. Jean are consistent with ocean island basalts.

rocks contain mafic blocks that provide evidence for fractional crystallization at mid crustal depths (Arculus et al.,1980). This process may explain why Dominica is dominated by intermediate rocks, as cumulates likely removed mafic phases from the parent magma, leaving a more evolved melt to erupt. This study, however, finds no evidence for this fractional crystallization process at Fond St. Jean, and concludes that direct emplacement of the parent magma has occurred instead.

This study may be broadened in the future by utilizing mixing models to generally determine what type of mantle the parent magma was derived from, and what percent of the magma composition is due to sediment contamination. Unfortunately, the ability to model solid-melt processes and calculate a more specific mantle composition from which the parent magma was derived is limited by sediment contamination in these samples.

\section{ACKNOWLEDGEMENTS}

This material is based upon work supported by the Keck Geology Consortium and the National Science Foundation under Grant No. 1659322. I would like to thank Holli Frey and Laura Waters for their assistance and guidance throughout my project. I would also like to thank Steve Dunn for additional guidance and support.

\section{REFERENCES}

Arculus, R.J., and Wills, K.J.A., 1980. The petrology of plutonic blocks and inclusions from the Lesser Antilles island arc. Journal of Petrology 21, 743-799.

Brown, G.M., Holland, J.G., Sigurdsson, H., Tomblin, J.F., 1977. Geochemistry of Lesser Antilles volcanic arc. Geochimica et Cosmochimica Acta 41, 785-801.

Brown, R.J., Thordardson, T., Self, S., Blake, S., 2015. Disruption of tephra fall deposits caused by lava flows during basaltic eruptions. Bulletin of Volcanology 77, 1-15.

Halama, R., Bourdon, G., Villemant, B., Joron, J.-L., Le Friant, A., Komorowski, J.-C., 2006. Preeruptive crystallization conditions of mafic and silicic magmas at the Plat Pays volcanic complex, Dominica (Lesser Antilles). Journal of Volcanology and Geothermal Research 153, 200-220.

Hollocher, Kurt and Ruiz, Joaquin, 1995. Major and trace element determinations on NIST glass standard refererence materials 611, 612, 614 and 1834 by inductively coupled plasma mass spectrometry. Geostandards Newsletter 19, 27-34.

Howe, T.M., Lindsay, J.M., Shane, P.A., Schmitt, A.K., and Stockli, D.F., 2014. Re-evaluation of the Roseau Tuff eruptive sequence and other ignimbrites in Dominica, Lesser Antilles. Journal of Quaternary Science 29, 531-546.

Howe, T.M., Lindsay, J.M., and Shane, P.A., 2015. Evolution of young andesitic-dacitic magmatic systems beneath Dominica, Lesser Antilles. Journal of Volcanology and Geothermal Research 297, 69-88.

Lindsay, J.M., Trumbull, R.B., and Siebel, W., 2005. Geochemistry and petrogenesis of late Pleistocene to recent volcanism in southern Dominica, Lesser Antilles. Journal of Volcanology and Geothermal Research 148, 253-294. 
McDonough, W.F. and Sun, S.-s., 1995. The composition of the earth. Chemical Geology 120, 223-253.

Pearce, J.A. and Cann, J.R., 1973. Tectonic setting of basic volcanic rocks determined using trace element analyses. Earth and Planetary Science Letters 19, 290-300.

Plank, T., 2005. Constraints from thorium/lanthanum on sediment recycling at subduction zones and the evolution of the continents. Journal of Petrology 46, 921-944.

Smith, A.L., Roobol, M.J., Mattioli, G.S., Fryxell, J.E., Daly, G.E., and Fernandez, L.A., 2013. The volcanic geology of the mid-arc island of Dominica, Lesser Antilles_-The surface expression of an island-arc batholith. Geological Society of America Special Paper 496, pp. 249. doi:10.1130/2013.2496.

Wills, K.J.A., 1976. The geological history of southern Dominica and plutonic nodules from the Lesser Antilles. Ph.D Thesis, Durham University, 222pp.

Vermeesch, P., 2006. Tectonic discrimination diagrams revisited. Geochemistry Geophysics Geosystems 7, 1-55. doi:10.1029/2005GC001092. 